\title{
Ferghana in the Period of Amir Timur's Struggle for Power (1360-1370)
}

\author{
Usmonov Bahriddin
}

\begin{abstract}
The article analyzes the political processes that occurred in the Ferghana Valley during the years of the struggle for the power of Amir Temur. During the analysis, by comparative and critical study of the information available in historical sources, the role and importance of the Ferghana Valley in the political life of Maverannakhr were highlighted. As for the studied period of the history of the Ferghana Valley, sources only contain information on Khojend, the analysis was carried out using the example of this property. Attention is drawn to the fact that the neighborhood with the nomadic state Mogolistan had a great influence on the political reality of the Ferghana Valley. Also, on the basis of a critical review of the historical and political events described in the sources, the author provides new conclusions.
\end{abstract}

Keywords: Maverannakhr, Mogolistan, Ferghana, Khojend, Amir Temur, Bayazid Jalayir, Zafarname.

\section{INTRODUCTION}

The history of the period of Amir Timur is one of the widely studied topics in historiography. In Uzbekistan, a lot of scientific research on this topic was published during the years of independence. Despite this, the issues of political, socio-economic and cultural development of the Ferghana Valley in the era of Amir Timur still remain poorly understood.

In the scientific literature on the history of the Ferghana Valley $1360-1370$ years. only fragmentary information is found. So, when it comes to political fragmentation during this period, mention is made of the Khojent bekty formed in this region [Amir Temur zhanon tarikhida, 2001, p. 60-61; Axmedov, 1996, p. 302], whose hakim Bayazid Jalayir during the campaigns of the Khan of Mogolistan Tugluk Temurkhan in Maverannahr in 1360 and 1361 was one of the first to obey him, but nevertheless, he was put to death [Axmedov, 1996, p. 312-315]. It is also noted that after the separation of the Chagatai ulus into two parts, Ferghana became part of the Mogolostan [Bartold, 1963, p. 512; Axmedov, 1994, p. 178].

Problems still remain unexplored: the place of Ferghana in the political life of Maverannahr, the gradual expansion of the borders of the Khojent beks, the change of beks (hakims), their participation in internecine wars, the political motives for their entry into the state of Amir Temur. Below we will try to state our thoughts on these problems.
Sources and scientific literature state that on the eve of the formation of the state of Amir Timur in Maverannahr, there was political fragmentation: the country was divided into a number of backs. For example, in Samarkand, the Emir Bayan Sulduz ruled, Keshe - the emir of Haji Barlos, Shiburgan - Muhammad Khoja Apardi, etc. [Shomiy, 1996, p. 28; Samarkandi (manuscript) p. 104, Khondamir, 2013, p. 39].

The information cited in the sources about the political fragmentation of that time is almost identical, but they do not say anything about the backs that arose in the northeast of Maverannahr. The only becky mentioned in this part of Maverannahr was the Khojent flight, whose ruler was Emir Bayazid Jalair. The question of which becki included Tashkent, Akhsi, Margilan, Andijan, and what were the borders of the Khojent beqi remain open.

\section{METODOLOGY}

We considered it appropriate to express our thoughts on this issue, based on historical sources - the works of Sharafiddin Ali Yezdi, Nizamiddin Shami, Muhiddin Natanzi, Fasih Khawafi, Abdurazzok Samarkandiy, Mirhond and Hondamira. If Nizamiddin Shami in "Zafarnama" is limited to the phrase: "Khojent was under the jurisdiction of the Emir Bayazid" [Shomiy, 1996, p. 28], then Sharafiddin Ali Yezdi in his eponymous work gives information that "Khojent was ruled by the Emir Bayazid Dzhalair" [Yazdiy, 1994, p. 60]. And Muhiddin Natanzi in his work "Muntahab ut-tawarikh Muini" claims that Khojent is the place of residence of the Jalair tribe: "Emir Bayazid conquered Khojent, where the Jalair lived" [Natanziy, 2011, p. 50]. Although the information in all three works is very brief, they allow us to draw some conclusions.

As you know, in 1358 the Emir Abdullah's son and heir, Emir Abdullah, was removed from power by the Emir Bayan Sulduz and Emir Haji Barlas who rebelled against him [Khawafi, 1980, p. 87]. As a result, political fragmentation began in Maverannahr, and, as mentioned above, several independent backs appeared in the country. Since that time, Emir Bayazid Jalair, who ruled Khodzhent initially, began to conduct an independent policy. 
Therefore, the phrase Muhiddin Natanzi: "Khujand conquered the Emir Bayazid", should not be taken literally: as if he had conquered it, coming from another locality. According to the literature, Bayazid was the chief emir of the Khojent Jalairs.

For example, historians A.Yu. Yakubovsky, A. Akhmedov and H. Bababekov adhere to this opinion [Yakubovsky, 1946, p. 52-53; see Yazdiy, 1997, p. 316. 75 comments.]. V.V. Bartold also claimed that the Jalair tribe lived in the vicinity of Khojent. In order to show the political and economic situation of this tribe, he applies the term "ulus" to their association [Bartold, 1964, p. 34, 49].

The fact that from the northeastern territories of Maverannahr only Khojent is mentioned in the sources testifies to the great influence of the emir of this region Bayazid Jalair in Tashkent and the Ferghana Valley. Indeed, in this region there was no more powerful and powerful ruler than Bayazid. No wonder Nizamiddin Shami used the expression: "The Khojent state was under the jurisdiction of the emir Bayazid." Calling the possessions of other Emirs Region (provinces), he mentions the possessions of Emir Bayazid Jalair as "Khojent State".

This means that its territory was not limited to one Khojent province. In this situation, the influence of Emir Bayazid could expand in the north only towards the Tashkent province, and in the east - towards the central and eastern lands of Ferghana. The spread of the influence of Emir Bayazid Jalaiir in the central regions of Maverannahr is observed later and only for a short time.

When in 1360, 1361 the ruler of Mogolistan Tugluk Temurkhan invaded Maverannahr, both times he was the first to go to meet his emir Bayazid. The sources do not give information about the situation in Tashkent and Ferghana in this situation.

Based on reports cited in historical sources about the administrative structure and political situation in the northeast of Maverannahr, in particular, in the Ferghana Valley, the following facts can be noted. At the time when Amir Timur entered the political arena, that is, in the middle of the XIV century, in the administrative structure of the Ferghana Valley, Khojent province occupied a special place.

When in 1360, 1361 the ruler of Mogolistan Tugluk Temurkhan invaded Maverannahr, both times he was the first to go to meet his emir Bayazid. The sources do not give information about the situation in Tashkent and Ferghana in this situation. In 1360, under the pretext of restoring the Chagatai ulus, the Mogolistan Khan Tugluk Timur invades Maverannahr. When his large army reaches the place of Chanak Bulak in Tashkent province, the emir Bayazid Jalayir with his army surrenders to the khan.

Although this event is also described in a similar way in the sources, there are some differences in the details. So, Nizamiddin Shami writes: "He reached Chanak Bulak, located two distances (manzil) from Samarkand. After holding a council with his emirs and statesmen, he instructs Tuk Timur, the emir of Khoji Erkuniti, and the emir of Bekizhak from the Kerayit tribe to go to Maverannahr. He ordered them to submit to Bayazid Jalayir. The emirs, having received the order of the khan, hit the road. When they reached the Khojent border, the emir Bayazid Jalayir joined them with his army, and they went towards Shakhrisyabz [Shomiy, 1996., p. 29]. And Sharafuddin Ali Yezdi sets forth this episode as follows: "When Tugluk Temurkhan reached the place of Chanak Bulak, located in the Tashkent steppe near Khojent water (Syrdarya - B.U.), he holds a council with emirs and officials, and it was decided that Ulug Tuka Timur from the Kerayit clan, Hodzhibek from the Arkanut clan, Bikizhak from the Kangli clan will go forward as the vanguard.

All three emirs, according to the order, went forward. After they crossed Khojent water, Emir Bayazid Jalayir embarked on a path of reconciliation and joined them with his clan. Together they turned in the direction of Shakhrisyabz "[Yazdiy, 1994, p. 62-63]. Muiniddin Natanzi also notes that the emir Bayazid obeyed the khan and, as a guide, brought the Mughals to Samarkand and Shakhrisyabz [Natanziy, 2011, p. 52]. Also, Abdurazzak Samarkandi, Mirhond and Khondamir give almost the same information [Samarkandi, p. 104; Mirhond, p. fourteen; Khondamir, 2013, p. 39].

Analysis of these data allows us to draw some conclusions regarding the object of our study. Firstly, it should be remembered that at this time, Khojent was the largest province on the lands bordering Mogolistan. This is also confirmed by the fact that the Mongol army from Mogolistan through the Tashkent province came unhindered to the Syr Darya. Their first council in Chanak Bulak, without crossing the Syr Darya, shows that they passed through these lands both within their territory, and their influence in the Tashkent oasis was undeniable.

You should also pay attention to the message of Shami that the three emirs, assigned to control the vanguard of the army, were ordered to submit to Bayazid jalayir. Bayazid Jalayir did not participate in the council in Chanak Bulak. But, apparently, his envoy expressed the readiness of Bayazid to obey, since such an order was given on the council. Apparently, Bayazid Jalayir, although he sent his man out of caution to Tugluk Temur, nevertheless, without leaving Khojent, he waited for the other emirs of Maverannahr to behave. It was obvious that he alone could not do anything against the enemy.

From the information of Nizamiddin Shami and Sharafiddin Ali Yezdi it is clear that Emir Bayazid acted in two ways. He sends to Tugluk Temurkhan, who was standing in Chanak Bulak, his messenger, expressing readiness to obey, and at the same time, not leaving Khojent, waiting for help from other emirs of Maverannahr.

Published By:

Blue Eyes Intelligence Engineering 
Without waiting for help, and when the Mughal troops had already reached the borders of Khojent, he went out at the meeting to the Mughals and joined them.

In turn, Tugluk Temur, by attracting the emir Bayazid Jalaiir to his ranks and increasing his position, pursued several goals. The first of them is the strengthening of the Mughal army, and the second, and, one might say, the main goal is to urge other emirs of Maverannahr to come to him and surrender without resistance, and in this way to prevent the unification of scattered becks against him. That is why Tugluk Temurkhan, according to the information of Sharafiddin Ali Yezdi and Muiniddin Natanzi, appoints Emir Bayazid Jalayir as the leader of his army, and according to Nizamiddin Shami - the head of the emirs who were at the forefront (mangla).

As a result of the contradictions that arose between the Manglai beks sent to take Samarkand and Shakhrisyabz, the emirs of Maverannahr began to act somewhat freely. After the emirs of Jete, who were walking in the manga (vanguard), returned to Chanak Bulak, the emir Bayazid Jalaiir separated from them and joined Amir Temur and Khizr Yasavuri.

Subsequent events show that by the summer of 1360 the emirs of Maverannahr became much freer, and the danger of the Mughal conquest sharply decreased. But the local emirs began a struggle among themselves [Amir Temur zhanon tarikhida, 2001, p. 60-61]. Emir Hussein to fight against the emir Bayan Sulduz asks for help from Amir Temur, Bayazid Jalayir and Khizr Yasavuri. For Fasikh Khawafi, this information is stated differently:

Emir Hussein to fight against the emir Bayan Sulduz asks for help only from Amir Temur and Khizir Yasavuri [Khavafi, 1980, p. 89]. The same information from Honda is given as, Emir Hussein asks for help from Amir Temur and Boyazid Jalayir [Khondamir, 2013, p. 40]. After conferring, they decide that Emir Bayazid Jalayir returns to Khojent to observe the Mongolian army, and the other two emirs rush to help Hussein [Yazdiy, 1994, p. 62-63].

Indeed, at a time when Tugluk Temurkhan was standing with a large army near Khojent, it was advisable for Bayazid Jalayir to be in his possessions. Nizamiddin Shami notes that Bayazid Jalayir went on a journey for a personal meeting with Tugluk Temurkhan so that he would not have the wrong idea about the emirs of Maverannahr [Shomiy, 1996, p. thirty]. This meeting was also needed by Emir Bayazid Jalayir in order to find out further plans of Tugluk Temurkhan and the situation in his headquarters.

But when Bayazid Jalayir reaches Khojent, due to the intensification of hostility between the Mughal emirs, Tugluk Temurkhan returns to Mogolistan. As a result, the Maverannahra region, including Ferghana, regained their independence.

The events that took place in the summer and autumn of 1360 further enhanced the authority of Emir Bayazid Jalaiir.
After the defeat of emir Bayan Sulduz, an emir from the tribe of Sulduz Tugluk revolts against emir Hussein, which led to the beginning of new internecine wars. This time, in the fight against Tugluk Sulduz, Emir Hussein asks for help from Amir Temur and Khizr Yasavuri. Sharafiddin Ali Yezdi writes that Amir Temur notified Khizra Yasavuri and Bayazid Jalayir about this, and that Khizr Yasavuri came to the aid [Yazdiy, 1994, p. 71-72].

But Nizamiddin Shami does not mention the emir Bayazid at all in the description of the Tugluk Sulduz riot [Shomiy, 1996, p. 31]. Muhiddin Natanzi also provides interesting information. He describes how Tugluk Sulduz, in collusion with the emir Bayazid Jalayir, begins the fight against the emir Hussein [Natanziy, 2011. p. 54].

An analysis of the events shows that there is some truth in Natanzi's statements. In the interpretation of Sharafuddin Ali Yazdi, Emir Bayazid Jalayir did not intervene in this struggle, although he was notified of this by Amir Temur. On the contrary, he plans to conclude an alliance with Haji Barlas who has returned to Maverannahr [Khawafi, 1980, p. 89] and invade the possession of Khizr Yasavuri, who left with his army to fight against Tugluk Sulduz.

To implement this plan, Haji Barlas, with the help of the Emir Bayazid, will reorganize his army. Although Natanzi narrates that Bayazid Jalayir and Haji Barlas made a campaign against Emir Hussein [Natanziy, 2011, p. 52], in fact, they did not fight against the emir of Hussein, but his ally Khizr Yasavuri [Yazdiy, 1994, p. 72-73; Shomiy, 1996, p. 31]. If the real goal of Haji Barlas was to return Kesha vilayat, taken from him by Amir Temur with the help of Emir Bayazid, then the goal of Emir Bayazid was to get Samarkand.

It is known that the ruler of Samarkand, Emir Bayan Sulduz, frightened by the troops of the Mughal Khan Tugluk Temur, fled to Hisar. And after the departure of the Mughal army, a conflict arises between Bayan Sulduz and Emir Hussein. At a time when Emir Bayazid Jalayir, escorting the Mongol army, leaves for Khojent, Emir Bayan Sulduz was defeated by the allies of Emir Hussein - Khizr Yasavuri and Amir Timur. After this victory, the surroundings of Samarkand completely come under the control of Khizra Yasavuri. Keshsky region was at the disposal of Amir Timur.

This situation did not satisfy either the emir of Haji Barlas, who returned to Maverannahr after the departure of the Mughal army, or the emir of Bayazid Jalayir, who was afraid of increasing influence of Khizr Yasavuri. For this reason, an alliance of these two emirs has formed. Emir Bayazid Jalayir decided to take advantage of the rebellion raised by Tugluk Sulduz against Emir Hussein. 
The defeat of Khizr Yasavuri, who was an ally of Emir Hussein, the main contender for the administration of Maverannahr, was fully consistent with the interests of the ruler of Khojent, Emir Bayazid Jalayir.

Realizing the impossibility of expanding the Khojent territories in the northern and eastern directions bordering Mogolistan, the emir Bayazid was forced to advance only towards the central regions of Maverannahr.

In a situation where the threat of the attack of Mogolistan on Maverannahr increased every day, for border guard service this was the most important task. In the town of Okyor, near Kesh, the troops of the emir Khizr and Timur defeated Haji Barlas. And Emir Bayazid Jalayir, taking advantage of the fact that Khizr Yasavuri was at this time in Kesh, arrives with his army in Samarkand and captures the city. Haji Barlas was also forced to retreat towards Samarkand to join the emir Bayazid Jalayir. Emirs Khizr and Timur come with their troops towards Samarkand. But the soldiers of Amir Timur secretly leave the army and one by one join the army of Haji Barlas.

Their behavior can be explained by the fact that the position of these two large emirs was much better than the young emirs like Khizr Yasavuri and Timur. The massive shift of the Kesh troops to the side of the enemy led to the appearance of mistrust between Amir Timur and Khizr Yasavuri. In the end, Amir Timur was forced to join the emirs of Bayazid and Haji Barlas.

As a result, Khizr Yasavuri was defeated, and Samarkand remained in the hands of the ruler of Khojent, Emir Bayazid Jalayir, and Keshsky Vilayat was returned to Haji Barlas. Information on the consequences of this battle, given in all three sources, is very important. If Sharafuddin Ali Yezdi and Nizamiddin Shami emphasize that Emir Bayazid Jalayir sat on the throne [Shomiy, 1996, p. 31; Yazdiy, 1997, p. 24], Muiniddin Natanzi says about him "he became a ruler in the possessions of Zhend as a great (independent) emir" [Natanziy, 2011, p. 52]. The historian Gulam Karimi correctly noted that here Natanzi by Jend means Khojent.

In general, it can be seen from the sources that after these events, the emir Bayazid Jalayir began to manage Maverannahr. Other emirs of Maverannahr recognized him as a great emir ("Amir-ul umaro"). If we turn to the sources, it is clear that after the removal of the emir Abdullo from power, the reign passed to the emir Bayan Sulduz [Muiniddin Natanziy, 2011, p. 51.]. By the second half of 1360 , it became clear that such an opportunity was more for Emir Bayazid Jalayir. But in all three sources it is said that he, not remaining in Samarkand, returns to his possessions in Khojent. Consequently, the ruler of Khojent, Emir Bayazid Jalayir from the second half of 1360 to March 1361 , that is, for about a year he ruled Maverannahr from Khojent.

In March 1361, the Khan of Mogolistan Tugluk Temur again invades the borders of Maverannahr. After he, having crossed the Syrdarya, reaches Khojent, the emir Bayazid
Jalayir surrenders to him again and goes to the service of the khan. Large emirs Maverannahr emir Bayan Sulduz and Haji Barlas also decide to surrender to the khan. But a little later, the emir Bayazid Jalayir was executed by the khan [Samarkandi, p. 105]. In fact, apparently, Tugluk Temurkhan planned to execute all prominent emirs of Maverannahr, because, after some time, the emir Bayan sulduz was also executed. Another influential emir, Haji Barlas, although he was able to escape from Tugluk Temur, was killed by the conspirators in Khorasan.

Thus, the entire territory of Maverannahr, including the Ferghana Valley, is again transferred to the disposal of the Mughal khans. The sources do not have accurate information about who transferred the possessions of Emir Bayazid Jalayir. Perhaps the administration of Khojent province passed to the son of the emir Bayazid Jalayir Emir Ali Dervish. In 1366, Emir Bahrom Jalayir selected the Khojent vilayat precisely from Ali Darvesh and Musa. But on this basis it cannot be concluded that during the years 1361-1366 only Ali Darvesh governed the Khojent province. The sources do not have sufficient information confirming this fact. In the political events of 1361-1366, Ali Darvesh is hardly mentioned. This indicates that in these years the Khojent vilayat was part of Mogolistan.

In this regard, we should mention the Emir Bahr Jalayir, who for many years ruled the Khojent province. Emir Bahrom Jalayir was one of the emirs who lost their possessions during the Mughal rule. For the first time his name is found in the sources when describing the events of 1362. In 1362, Bahrom Jalayir together with Amir Timur left Maverannahr and sent to Kandahar. But he, not continuing cooperation with Amir Timur and Hussein, is leaving for India. The sources mention that he left for India without the permission of the allies, betraying them [Yazdiy, 1994, p. 87; Natanziy, 2011. 59].

Fringe Jalayir did not stay long in India. Probably, without going to India, he watched the situation in Maverannahr from the areas of modern Afghanistan bordering the Indus valley. Having returned from Seyistan, Amir Timur and Hussein are gathering troops from among those fleeing Maverannahr in the north of modern Afghanistan. It was at this time that Emir Bahrom Jalayir joined them. Although his name is not mentioned in the battle of Tashkuprik in 1363, but it is present among the military leaders sent to liberate Kesha after this battle.

It is known that in the battle of Tashkuprik Amir Timur involved only 2 thousand of 6 thousand soldiers, and the remaining 4 thousand were left in reserve under the leadership of Amir Hussein. Perhaps Bahrom Jalayir remained in this reserve unit. Natanzi writes: 
"Having composed five squads of two hundred horsemen and placed them at the head of Emir Suleiman, Emir Joku, Bahram, Emir Jalaliddin Barlas, Khoji Sayfiddin and Yultimur, he sent them to the steppe. In order for the dust to rise, and from afar it seemed that a large army was coming, he ordered a horse to be tied on a tree branch on both sides, and without stopping, reach Shakhrisyabz and capture the mayor appointed by the Mongols "[Natanziy, 2011, p. 59]. This trick of Amir Timur yielded results, and Shakhrisyabz was quickly released by two hundred soldiers. A little later, the Mongols were completely expelled from Maverannahr.

But, when it comes to subsequent events, for some reason the name of Bakhrom Jalayir is not mentioned. Almost all the emirs of Maverannahr took part in the "Mud battle" that took place in 1365 , but the name Bahrom Jalaiir is not among them.

Although Muiniddin Natanzi mentions that in the "Mud Battle" Bahrom participated with his squad in the rear guard of the troops [Natanziy, 2011, p. 65-68], however, Sharafuddin Ali Yazdi and Nizamiddin Shami note that a military leader named Sher Bahrom fought in the rearguard [Yazdiy, 1994, p. 104-113; Shomiy, 1996.S. 45]. Based on the fact that here Natanzi does not mention the name of Sher Bahrom Huttaloni at all, it can be understood that he confused him with Bahrom Jalayir.

Where was Bahrom Jalayir at this time and what was he doing? We can see that in the sources only emirs from the rearguard and flank units of the troops of Amir Hussein and Amir Timur are mentioned. The names of the emirs who were in the main part of the army under their leadership are not mentioned. Based on this, it can be assumed that the detachment of Emir Bahrom Jalayir was part of the military unit under the command of Amir Hussein, and his name was not mentioned because he could not distinguish himself in battle. If he had sided with Ilyaskhoji during the battle, this fact would also be reflected in the sources.

After Ilyaskhoja, who won in the "Mud Battle", having failed to conquer Samarkand, returns to his homeland, Bahrom Jalayir began to actively participate in the political processes of Maverannahr.

It is known that Amir Timur, having conferred with Bahr Jalayir and Sher Bahrom, begins the fight against Amir Hussein. In fact, the cause of the conflict between Amir Temur and Hussein was Amir Musa and Ali Darves. In order to punish them, Amir Temur sends an army to Khojent. "On this side, the great Sahibqiran," writes Sharafuddin Ali Yezdi, "gives troops to Bahr Jalayir, emir Chok and Abbas bahadir and sends them towards Khojent and orders them to seize the Jalayir lands, and also to take emir Mus and son Bayazid Ali Darvesh, whose lies and unrest were the cause of this enmity.

Learning about this, they fled. And Bahrom Jalayir himself became the ruler of the province ... "[Yazdiy, 1994, p. 122]. And Nizamiddin Shami separately notes that the Khojent vilayat belonged to Ali Darvesh. Describing how
Emir Musa and Ali Darves, the guilty parties to the conflict, having heard of Amir Timur's approach to Samarkand, left the city, the historian writes that Amir Sahibkiran sent Bahrom Jalayir, Amir Choku and Abbas Bahadur with a large army to capture the vilayat belonging to Emir Musa and Ali Darvesh "[Shomiy, 1996, p. 52, 54].

Having conquered Khojent Bahrom, the Jalaiir, without interfering in the conflict of both emirs, is trying to find support in Mogolistan. Although at the beginning of the struggle he was on the side of Amir Temur, a little later he took a neutral position. Feeling that he could incur the wrath of Amir Timur with his neutral position, he goes to Mogolistan.

\section{RESULTS \& DISCUSSIONS}

Nizamiddin Shami writes that Bahram Jalayir, foreseeing a bad thing, said: "We cannot resist Emir Hussein, now our business is bad." He quickly equipped the army and his people. Having plundered the possessions of Ali Darvesh, he kills some of them and then goes with his people towards Kahla. "Under Kakhla, the author apparently meant a mountain pass passing through the Ferghana Valley to Mogolistan. Because there are no mountain passes on the path leading to Mogolistan through Tashkent Vilayat and South Kazakhstan.

And Sharafuddin Ali Yezdi notes that Bahrom Jalayir "out of fear that it will be difficult to confront the khan and emir Hussein without notifying Sahibkiran, equips a detachment from his close associates and, killing the man Ali Darves, leads his people to Jeta" [Yazdiy, 1994, from. 122].

From the information of both authors it is clear that Bahrom Jalayir, together with his army, on the pretext of completing the task of Amir Timur, arrives from Samarkand to Khojent. Having defeated the army of Ali Darves in Khojent, he completely took control of the province. But he did not believe that Amir Timur would defeat Hussein, so he did not return to Amir Timur with Samir Choku and Abbas Bahadur in Samarkand. Realizing that he can be punished for this, he goes to Mogolistan through the northeastern regions of the Ferghana Valley.

But Muhiddin Natanzi does not at all mention that Amir Timur ordered Bahrom Jalaiir to make a trip to Khojent. As he notes, Amir Temur, Bahrom Jalayir and Sher Bahrom agree to fight together against Amir Hussein. By conspiracy, Bahrom Jalayir and Cher Bahrom depart for their possessions to collect troops. Having reached Khodzhent, Bahrom jalayir changes his mind and, not returning to Amir Timur, leaves for Mogolistan [Natanziy, 2011, p. 74]. 
But the information of Natanzi cannot be considered reliable, because at that time Khojent was owned by Ali Darvesh. Perhaps due to the fact that he had hereditary possessions in the area where the Jalayir tribe lived, Natanzi regarded Bakhrom Jalayir's campaign in Khojent as his arrival in his vilayat to gather troops.

It can be seen from the sources that Bahrom Jalayir, relying precisely on these possessions and the help of Emir Choku and Abbas Bahadur sent by Amir Timur, begins the fight against Emir Musa and Ali Darvesh.

Taking advantage of the fact that Amir Timur did not support these two emirs, and the emir Hussein was far away, behind the Amu Darya, Bahr Jalayir plundered the possessions of his main enemies from the Jalayir clan. In the end, he interrupts the supporters of Ali Darvesh and himself becomes the leader of the Jalayirids. Although a little later he was forced to leave for Mogolistan, he managed to solve an important problem for himself, that is, to destroy his enemies among the Jalayirids.

Subsequent events show that another goal of Bahrom Jalayir's campaign in Mogolistan was to establish his power in the eastern vilayats of Maverannahr with the help of a khan. The struggle between Amir Timur and Amir Hussein gave him an opportunity to carry out his plan. This is also proved by the victories won by Bahrom Jalayir.

The name of Bahrom Jalayir, who left for Mogolistan in 1366 , is mentioned in the description of the events of 1367 1368 in connection with the 7,000-strong army he brought from there. Naturally, he did not stay in Mogolistan for more than two years. When the conflict between the two emirs escalated in Maverannahr, he returned to Khojent again. Later, in order to subjugate the other vilayats located around Khojent, he, together with the emir Kayhusrav, again goes to ask for help in Mogolistan.

In general, in 1367-1368, Bahrom Jalayir, with seven thousand auxiliary troops brought from Mogolistan, conquered not only Khojent, but also the territories of Tashkent and Sairam. He also seeks to receive a letter from the Khan of Mogolistan, Ilyaskhodzhi, on the right to control the province and the army. In the years 1367-1368, the influence of Bahrom Jalayir reached such a strength that even Amir Timur was forced to reckon with him.

Nizamiddin Shami tells of it this way: "As for the history of Kaihusrau and Bakhrom, they went to Mogolistan and, having brought in a seven-thousand-strong army under the command of Kuchuk Temur and Durovul, they stop in Tashkent. Amir Sahibkiran also turned the bridles of his will there ... Since the tsar's (Tugluk Temur) decree was issued so that the army and people of the Vilayat would obey Bakhrom, he would conquer (Tashkent) Vilayat by order of the Emir Sahibkiran. ... But since (Bahrom) went to visit the king (Tugluk Temur), the king respected him and forgave him for wrongdoing.
Despite all this, invited him to fight against the enemy. But he, not accepting this proposal, did not embark on the path of consent and cooperation "[Shomiy, 1996, p. 67-68). Although Nizomiddin Shami and other historians note that Kaihusrah and Bahrom Jalayir together led the army from Mogolistan, the fact that the letter was issued in the name of Emir Bahrom Jalayir shows that he was in leading positions. And Muiniddin Natanzi notes that the seven thousandth Mughal army was brought precisely by Bahrom Jalayir.

Amir Timur wanted to use Bahrom jalayir and his large army in the fight against Amir Hussein. But Bahrom Jalayir, who was increasingly strengthening his power in the eastern part of the Mavernenakhr, was interested in the internecine struggle between them and chose not to intervene in this conflict. Sharafuddin Ali Yezdi, noting that Emir Bahrom Jalayir did not want to help Amir Timur, emphasizes that he, under the pretext of collecting taxes for the Mughal khan, took control of the surrounding Tashkent, subordinate to Amir Timur [Yazdiy, 1994, p.165].

According to Natanzi, after Amir Timur found out that Hussein had sent a army of twenty thousand against him, he tried to attract Bahrom jalayir to the fight against him. "After the glory of that army spread throughout Turkestan," writes Natanzi, "Sultan Gazi began to persuade Bakhrom Jalaiir and Kaihusrava to go out to fight them. Fringe Jalayir did not heed the requests "[Natanziy, 2011, p. 83]. Khondamir also notes that Bahram Jalayir did not want to help Amir Timur [Khondamir, 2013. p. 64)].

In this regard, the issue of the governorate, for the management of which Ilyaskhoja's letter was given, should be clarified. Sharafuddin Ali Yezdi, arguing that Bahrom Jalayir was in Tashkent, notes: "Due to the fact that the khan issued a decree that the army and people of that province should be taken over by Bahrom, he (Bahrom) became the ruler of that province". By this, he indicates that Tashkent was mentioned in the letter. Nizamiddin Shami also noted that this province was Tashkent. But Muhiddin Natanzi gives the following information on this issue: "Bahrom Jalayir, bringing nearly seven thousand horsemen, stood in Sairam and Tashkent.

Sultan Gazi joined them. Bahrom Jalayir, having received a letter from the Mughal khan, took possession of Turkestan "[Natanziy, 2011, p. 82]. Considering that the sources of that time the Syr Darya cities and Tashkent vilayat were called Turkestan, it becomes clear that according to the khan's letter, Bahrom Jalayir was entrusted with the administration of the Maverannahr vilayats bordering with Mogolistan. Thus, it is striking that the Mughal khans again tried to subjugate Maverannahr, or, at least, have influence on its eastern part. 
In general, over the years, besides Khojent, Bahrom Jalayir took possession of the Sairam and Tashkent provinces. Although we do not have accurate facts, we can conclude that the central and eastern parts of the Ferghana Valley in these years also obeyed or were under his influence. It was natural that Bahrom Jalayir, who was the ruler of Khojent, considered the western part of the Ferghana Valley, subjugating Tashkent and Sairam, took control of the rest of the valley.

Although in 1367-1368 Bahrom Jalayir did not want to obey and help Amir Timur, and reached the point that he even appropriated his possessions, in the end he was forced to recognize the power of Amir Timur.

By this time, Tashkent and Sairam also left his submission and completely came under the influence of the Mongol emirs. In the late autumn of 1368, the Mongol emirs invaded Maverannahr and captured the Syrdarya cities and Tashkent province. As winter approached, they decided to winter here and spring to go to the inner regions of Maverannahr. But between them again a conflict arises, and closer to the spring of 1369 they return back to Mogolistan. But, in our opinion, some of the emirs remained here with their troops. The events of Amir Timur's campaign in Mogolistan in 1371 can serve as proof of this. Thus, Tashkent and Sairam also leave the order of Bakhrom Jalayir. But, despite this, his influence was still significant.

In the campaign against Amir Hussein in 1370, he participated in the ranks of the forces of Amir Temur gives his wife to Bahrom Jalayir the daughter of the khan of the Chagatai Ulus Tarmashirin - Sevinch Kutlug aha, testifies to the fact that his political influence was strong. Through this marriage, Emir Bayazid Jalayir also becomes a Khan's sonin-law and becomes the Kuragon.

\section{CONCLUSION}

In conclusion, we can say that as a result of the wars that began after the death of Emir Kazagan, Maverannahr is divided into several small beks. But in the sources there is no information about the backs that arose in its north-eastern part. Only Khojent bekim, which was at the disposal of the Jalayir tribe, is mentioned. This becky included only the western part of Ferghana, but not the entire Ferghana Valley. Despite this, due to the fact that there is no information about the presence of any political forces in the central and eastern regions of the Ferghana Valley, we can assume that these territories were also influenced by Khojent.

However, it is striking that in the Ferghana Valley, especially in its northern and eastern parts, there was a strong influence of the neighboring Mongolian state. These lands served as the closest target of robbery for the Mongol emirs. Perhaps that is why Mirzo Khaidar, in his work "Tarihi Rashidi", discussing cities belonging to the influential Mongolian Duglat tribe, mentions such large cities of the Ferghana Valley as Uzgen, Kasan, Akhsikat and Andijan [Khaidar, 1996, p. 26; Xaydar, 2010, p. 60].
In addition, the unhindered passage of the Khan of Mogolistan Tugluk Temur to the Syrdarya, flowing along the southern part of the Tashkent region, he first conducted a kurultai about this campaign in Chanak Bulak, without crossing the Syrdarya, and only after that he begins a campaign in the central regions of Maverannahr, indicates that in the northern and eastern regions of Maverannahr, bordering Mogolistan, their influence was very strong, that the Mongols considered these lands their possessions.

Khojent beking, located in the western part of the Ferghana Valley, as the territory adjacent to the strong nomadic state - Mogolistan, in this difficult situation not only preserved its existence, but at some moments could improve its position. If Emir Bayazid Jalayir from summer 1360 to spring 1361 was able to take control of Samarkand too, then Emir Bahrom Jalayir in 1367-1368 was able to subjugate the cities of Tashkent and Sairam. By 1369-1370, as a result of a sharp increase in the influence of Amir Timur in Maverannahr, the establishment of dominance of the Mongol emirs in the Tashkent province, the Khojent becki recognized the power of Amir Temur and became part of its state.

\section{REFERENCES}

1. Amir Timur in the world history. Ed. Editor: $\mathrm{H}$ Karamatov. Authors: S. Saidkosimov (leader), A. Akhmedov, B. Akhmedov and others. Enhanced and revised second ed. Tashkent, 2001.

2. Axmedov B. Tarihdan saboqlar. - T .: Kituvchi, 1994.

3. Axmedov B. Amir Temurni yod etib. - T .: Uzbekistan. 1996.

4. Bartold V.V. Compositions. T. 2. Part 2. M., 1964 [Bartold V.V. Sochineniya (Writings). Vol.2. P.2. Moscow, 1964

5. Yazdi, Sharafiddin Ali. Zafarname. Authors of the preface, comments and indexes A. Ahmad and $\mathrm{H}$. Bobobekov. Tashkent, 1997

6. Mirkhond. Ravzat al-safo fi siyrat al-anbiyo val mulk val hulofo. Electronic version of the manuscript from the library of the University of Michigan.

7. Natanzi, Muiniddin. Muntakhab ut-tavorikhi Muiny Author of trans. from Persian, preface and comments Ghulam Karimi. Tashkent, 2011.

8. Samarkandi, Abdurazzak. Matla as-sadayn va majma albakhrain. Electronic version of the manuscript from the library of the University of Michigan].

9. Khavafi, Fasikh. Mudjmal-I Fasikhi. Trans., preface, notes and indexes by D. Yu. Yusupova. Tashkent, 1980.

10. Khaydar Mirzo, Mukhammed. Tarikh-i Rashidi. Preface, translation from Persian by A. Urunbayev, R.P. Djalilova, L. M. Yepifanova, comments and indexes by R.P. Djalilova and L. M. Yepifanova. Tashkent, 1996.

11. Khaydar Mirzo, Mukhammed. Tarikh-i Rashidi. Preface, translation from Persian by V.Rakhmanov and Ya.Egamova. Tashkent, 2010.

12. Khondamir, Giyasiddin. Khabib us-siyar fi akhbori afrodi bashar. Preface, translation from Persian by Jalil Khazratkulov, Ismail Bekjonov, comments by Ashraf Akhmedov, Ismoil Bekjonov. Tashkent, 2013. 
13. Shami, Nizamiddin. Zafarname. Trans. from Persian by Y. Khakimjonov, processing and preparing the translation for publication and the responsible editor A.Urinbaev, compiler of comments and vocabulary H.Karamatov (comments to geographical names $\mathrm{O}$. Buriev), trans. from the Persian "Zail" ("Appendix") of Khafiz Abru to "Zafarname" by A. Buriev. Tashkent, 1996.

14. Yazdi, Sharafuddin Ali. Zafarname (Events in Maverannakhr (1360-1370). Released. Ed., preface and preparation for publication by A. Urunbaev, translated by O. Buriev. Tashkent, 1994.

15. Yakubovsky A.Yu. Timur (Experience of brief characteristics). // Voprosy istorii (Issues of history). 1946. No. 8-9. P. 42-74. 